\title{
Eye trackers in evaluation of transformation of historical monuments. Revitalisation of the Dresden arsenal
}

\author{
Marta Rusnak ${ }^{1, *}$, Joanna Szewczyk ${ }^{1}$ \\ ${ }^{1}$ Departament of history of architecture, art and technology Faculty of Architecture, Wrocław \\ University of Science and Technology str. Bolesława Prusa 53/55, 50-377 Wrocław, Poland
}

\begin{abstract}
The paper concentrates on the application of an eye tracker as a tool used to evaluate the successfulness of transformations of various historic monuments for modern purposes. An eye tracker as a device capable of registering the path of one's gaze makes it possible to analyze the way in which people perceive a given architectural object - in the case of this paper it is the former Dresden Arsenal, now known as the Bundeswehr Military History Museum. Since Daniel Libeskind, the architect behind the transformation, clearly defined the impression he what to achieve and the building provokes significant controversies, it was decided that it would be a suitable object for such a study. The survey was meant to find out whether the changes introduced by Libeskind actually helped him achieve the intended goal. The participants of the survey were shown images of the Arsenal's façade from before the transformation, after the transformation in the daytime and after the transformation, but at night, with the illumination turned on. The paper not only shows and analyzes differences in the way people perceive these three images, but also raises a question as to the potential of eye trackers as tools used in architectural research.
\end{abstract}

\section{Introduction}

Among the views of experts dealing with architecture and urban development one can often encounter references to historical monuments that have been inappropriately revitalized. Such critique may be related to the transformations changing the shape and size of the given structure as well as to less destructive adjustments such as poor illumination of historical surfaces. One can frequently hear terms such as disintegration, oppression, deformation or contradiction in relation to the monument's original concept and composition [1-5]. It may appear that such a state of things is largely due to the fact that so far all decisions as to such issues as the design of the monument's illumination or the rearrangement of its surroundings have been the matter of purely subjective views of conservators, architects and urban planners, whose actions and reasoning have often proved incomprehensible to regular citizens. The problem is due to the fact that the new aesthetic ideas related to making use of the potential of historical monuments are in no way objectively evaluated.

\footnotetext{
${ }^{*}$ Corresponding author: martajaszcz@wp.pl
} 
It appears that a solution to this problem may come in the form of an eye tracker. Eye trackers are nowadays the most popular devices responsible for registering the behavior of a person's eye balls. These devices send beams of infrared light towards the eyes. The video camera of an eye tracker records the movements of one's eyes and an analytical program identifies and processes the positions of pupils as well as the locations where the light beams get reflected. Thanks to automatic calibration enabled by the eye tracker's software, an algorithm adjusts itself to the individual characteristics of each user. As a result, the current direction of vision is calculated and it becomes possible to record the path of one's gaze. The points the observer focuses on have been called fixations, while the jumps in between them have been named saccades [6,7]. An eye tracker makes it possible not only to count the number of fixations and saccades, but also to describe their sequence and duration. Such data can be then mathematically interpreted, and turned into bar graphs, tabular summaries and charts depicting the changes in one's perception. The path one's eyes follows while looking at given images can be allotted to predetermined Areas of Interest. Such division makes it possible to depict mathematically the tendencies and trends present while perceiving a specific visual stimulus. Eye trackers are therefore commonly used in marketing, psychology, sport, medicine, but to virtually no extent in architectural research.

Such an attempt has been made by the authors of this paper. A survey, carried out in 2017, focused on two aspects of transformation applied to the historical façade of the former Dresden Arsenal, which now serves as a military museum. The first aspect was related to how the perception of this building changed after it had been renovated and extended; the second was related to the role of the building's illumination. The aim of the survey was to evaluate to what extent the present perception of this historical monument corresponds to the original concepts of Daniel Libeskind, who prepared the design for the transformation, and thus to present the potential of an eye tracker as an objective tool that can be applied in architectural research.

\section{The Dresden Arsenal}

The subject of the research is a former arsenal that has been adapted as a museum [8]. The building fell short of the expectations of its users, which is why it was extended in 2010-2011 according to the design of Daniel Libeskind. The change was supposed to result first and foremost in increased exhibition area, but it actually transformed the building into an architectural icon. Since the former Dresden store of weaponry, visible in $19^{\text {th }}$ century illustrations, was turned into the current seat of the Bundeswehr Military History Museum it has caused a considerable amount of controversy. Libeskind is famous for his ability to expressively incorporate numerous difficult historic experiences in his designs and the transformation of the former arsenal is no exception [8]. While planning the adaptation, Libeskind focused on making changes that would vividly represent the past of Dresden, a city destroyed during the late WWII Allied forces' air raids. These dramatic events received a contemporary symbol in the form of a wedge added to the building of the former arsenal, virtually cutting into the historical structure [8]. Moreover, this change is not the only element of dialogue between the old and the new, between the prewar and the contemporary image of Dresden. As openwork has been used in the added part, any change in how the building is lit affects the impression it makes. It is most visible at night, when the new illumination system emphasizes the partial transparency (fig. 2D) - the light from inside the wedge makes it possible to see things barely noticeable during the day, that is the details of the original façade.

The authors of the survey paid lots of attention to Libeskind's summary of his idea for this project, which is as follows: "I did not intend to preserve the façade of the museum and add an invisible extension at the back. What I wanted was a brave change, a dislocation, a test of the historic potential and creation of a new meaning. Architecture will engage 
people to a full degree of how the history of violence, military traditions, and the city's past all intertwine" [11]. Both experts and everyday observers may argue whether or not Libeskind achieved his goal, but these groups base their often mutually exclusive opinions on highly individualized, subjective perspective.

The controversies arise due to a lack of tools that would allow an objective evaluation of the degree to which Libeskind's design is in accordance with his intentions. There are of course some elements of the transformation that can be described mathematically: as a result of the changes, the surface of the façade (Fig. 1A) as seen frontally (Fig. 2) was increased by $25 \%$ (authors' estimations). The added structure covers $14 \%$ of the façade of the former arsenal and thus breaks its continuity, transforms the composition from a calm, symmetrical one into a dynamic, asymmetrical one. Unfortunately, without employing other tools an objective number-oriented evaluation of the visible consequences of the adaptation must end here. It is only thanks to using an eye tracker that a larger number of mathematical data can be obtained and analyzed.

\section{The survey}

A stationary RED $250 \mathrm{~Hz}$ eye tracker was used in the survey. The experiment was presented on a 21 " screen by means of the Experiment Center SMI software ${ }^{2}$. Three images were used as the stimulus shown during the experiment. Two out of these three were photographs of the façade of the Bundeswehr Military History Museum. The first was taken during the day (Fig. 1A), and the second was taken at night (Fig. 1D). The images had been processed in such a way that their final versions were the same size, had the same proportions, resolution and composition. In the night photograph no clouds are visible, the background is plain and does not attract attention. The daytime photograph has been modified - the clouds have been erased and replaced with a light blue gradient (Fig. 1B). The clouds could distort the results of the experiment due to their complicated, highly dynamic form. Thanks to all the preparation, both façades could be compared as they no longer included elements that could draw attention away from the primary matter of the experiment. The third image used in the survey had been edited (Fig. 1D) - the expressionist wedge added by Daniel Libeskind had been erased and so a façade was obtained that had the proportions of the original classicist building. This image was meant to serve as a reference point for the comparison between the day and the night photos of the structure.

The photos were shown over the course of three days. Each day a different group of adults, between 18 and 40 years old, took part in the survey. All of them had no eye illness that could affect the eye tracking recording and none of these people were architects, conservators or art historians. The participation of such individuals had been rejected on purpose because their education and knowledge of modern architecture might affect the way they look at objects related to their professional life and thus distort the credibility of the survey which focused on average, statistical perception of a particular object. For the same reason, the volunteers taking part in the experiment did not know the exact aim of the research so that the way they looked at the images was as spontaneous and natural as possible. The form completed before the experiment only informed the participants that the survey is related to architecture. Finally, just before the experiment proper all volunteers were asked to look at the pictures and try to determine if the set of images included any locations from Wrocław, the city they all lived in. It was an important step from the psychological point of view as this way all observers had the same false goal, which made all of them intellectually engaged to a similar degree. After the experiment all volunteers were asked if they had known the presented images. None of the studied people admitted having seen the Dresden Arsenal before the survey.

\footnotetext{
${ }^{2}$ SMI - Senso Motoric Instruments, more information can be found at https://www.smivision.com/.
} 

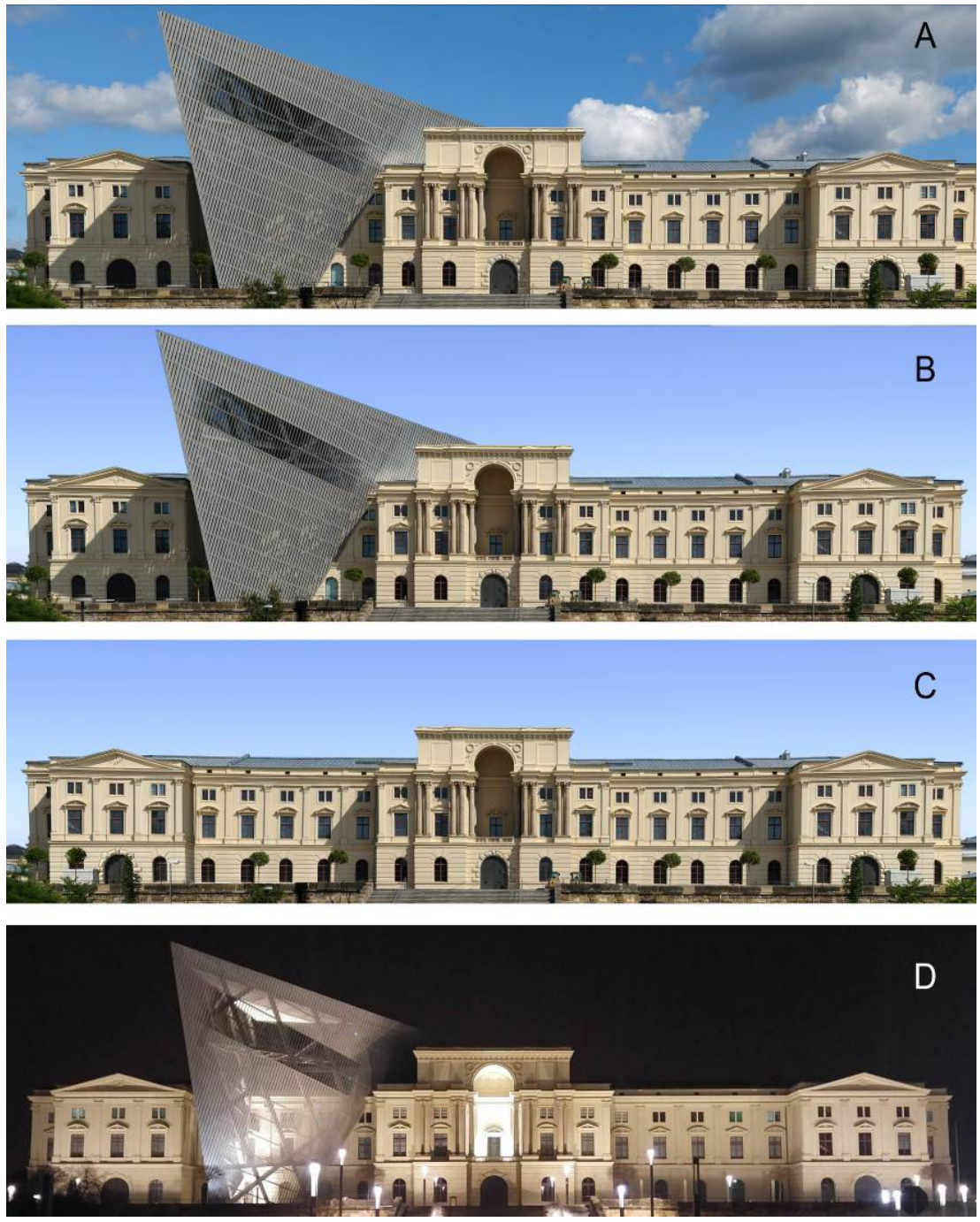

Fig. 1. Dresden arsenal façade (fig. MR).

The images were presented randomly among nine other images related to historical monuments. The three photos employed in the experiment were looked at by a total number of 64 people ( 36 women and 28 men), who agreed to take part in the survey and filled in the online application form ${ }^{3}$. Four recordings (of two women and two men) were deemed badly calibrated $^{4}$ and were not suitable to be used for further analysis. The researchers did not want the same group to compare two pictures of the arsenal and that is why the set presented on the first day did not include images $\mathrm{B}$ and $\mathrm{C}$, the one shown on the second day omitted images $\mathrm{C}$ and $\mathrm{D}$, whereas the third day set lacked images $\mathrm{A}$ and $\mathrm{D}$. As a result 20 recordings were used of people perceiving image $\mathrm{B}$, and images $\mathrm{C}$ and $\mathrm{D}$ were viewed by 22 people each.

The time limit for observing the image was set at 8 seconds. It was based on time limits set by other researchers in their experiments $[14,15]$ but also on the study, carried out by the

\footnotetext{
${ }^{3}$ Prepared by the Student Research Club "ArcHist".

${ }^{4}$ The problems with calibration might have been due to the errors of the researchers as well as to the hidden defects of vision.
} 
authors, of the changes in perspective one might experience while actually moving on foot across the square in front of the real Dresden museum. 8 seconds was a period during which the changes in the perspective of a person traversing the square both right in front of the museum and on its other end were of little import. The schemata of this simple graphic analysis is presented in fig. 2. Moreover, lab tests were carried out before the proper experiment in order to check how long a visual stimulus presented on a computer screen remains interesting to the viewers - for images shown for more than 8 seconds there was a noticeable rise in the number of people whose gaze strayed away from the screen.

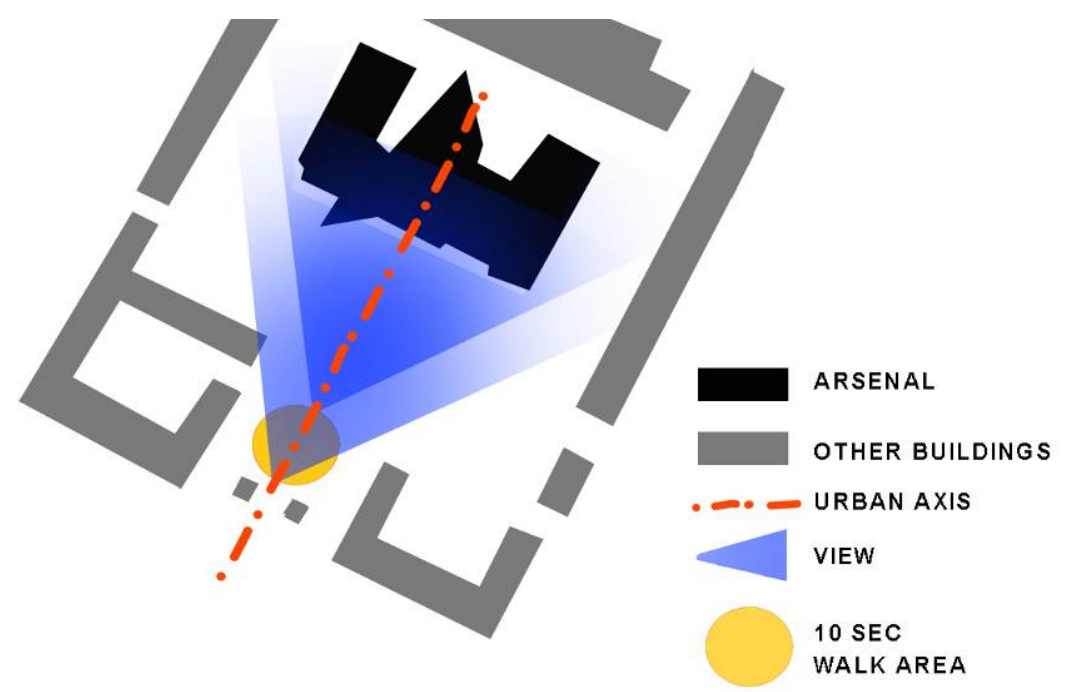

Fig. 2. Analysis of the change in perspective during an 8 -second-long period of movement across the square in front of the arsenal's building (MR).

The act of looking at each of the three stimuli began from the same spot thanks to placing so-called spacers, plain grey sheets with a distinct dot in the center. After one's vision was focused on the red dot for $800 \mathrm{~ms}$, a new image appeared. The entire process looked exactly the same for each participant in order to make the survey as credible as possible.

SMI's BeGaze software was used to interpret the obtained data [11]. Figure 3 presents the location of the Areas of Interest. Once such division had been made it was possible to make a comparative analysis. 

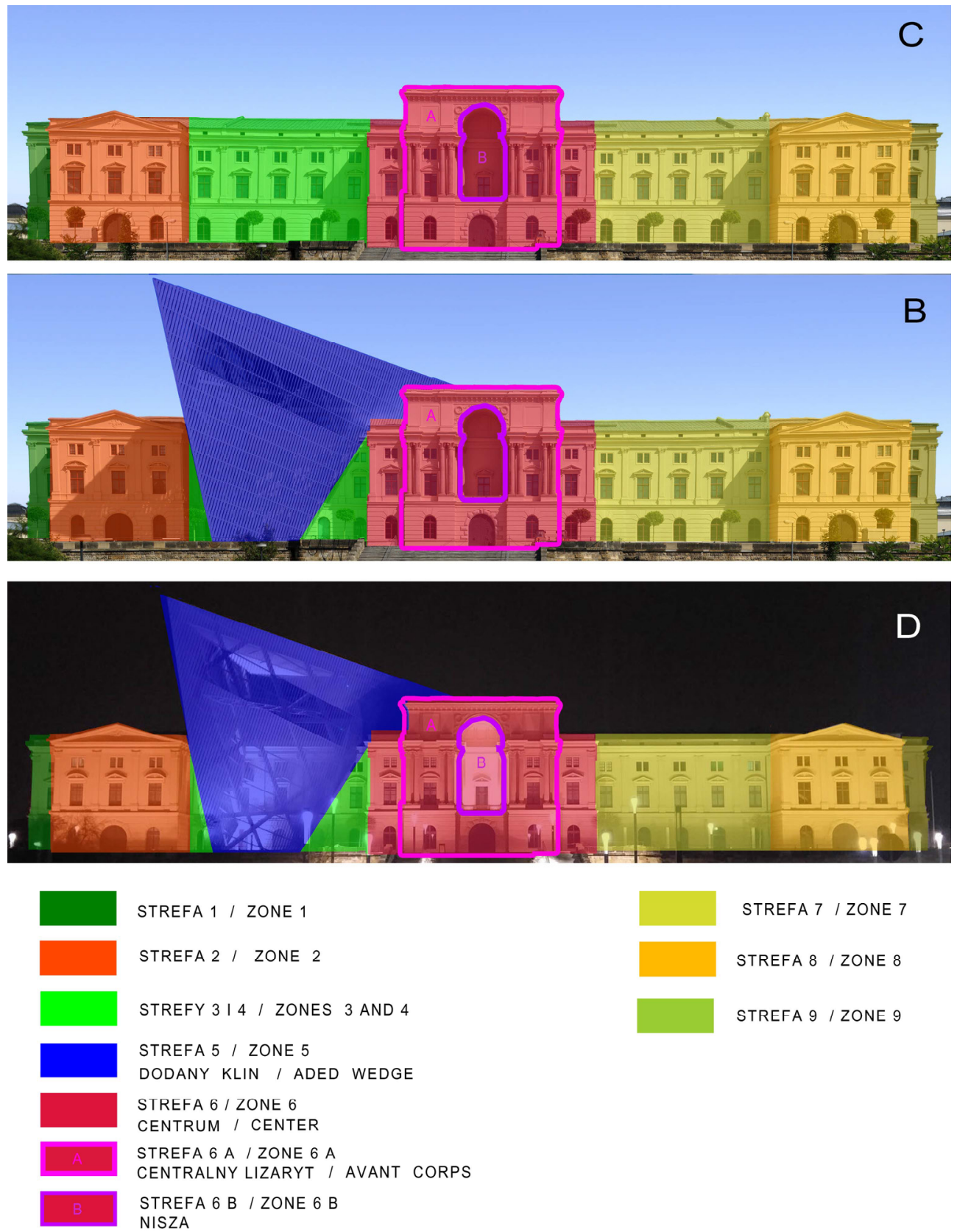

STREFA $7 /$ ZONE 7

STREFA 8 / ZONE 8

STRETA 9 / ZONC 9

Fig. 3. Location of Areas of Interest marked on figures $2 \mathrm{~B}, \mathrm{C}$, and D. 


\section{The results}

The obtained data suggests that the building lacking the modern addition designed by Daniel Libeskind (Fig. 1C) proved to be visually least attractive. During the 8 seconds the participants looking at this image made an average of 26.1 fixations. They spent $13.9 \%$ of the time, so over one second, looking at the areas of the image where there was no façade. The other two images appeared to be more appealing. Image $1 \mathrm{~B}$ required on average 31.4 fixations ( $20 \%$ more than $1 \mathrm{C}$ ), and image 1c provoked an average of 30.2 fixations (16\% more). Moreover, in both cases the observers spent much less time looking at other things than the façade of the building ( $8.6 \%$ and $7.9 \%$ respectively). One may also notice that the introduced illumination did little to affect the perception of the entire structure even though it increased the dynamics of the cognitive process (see table 1).

Table 1. General analysis of how observers focused on the building. Comparison for the three images.

\begin{tabular}{|l|c|c|c|}
\hline & $\begin{array}{c}\text { BUILDING } \\
\text { WITHOUT THE } \\
\text { WEDGE }- \\
\text { DAY } \\
\text { fig.2C }\end{array}$ & $\begin{array}{c}\text { BUILDING WITH } \\
\text { THE WEDGE }- \\
\text { DAY } \\
\text { fig.2B }\end{array}$ & $\begin{array}{c}\text { BUILDING WITH } \\
\text { THE WEDGE - } \\
\text { NIGHT } \\
\text { fig.2D }\end{array}$ \\
\hline $\begin{array}{l}\text { ENTIRE } \\
\text { IMAGE }\end{array}$ & 26.1 fixations & 31.4 fixations & 30.2 fixations \\
\hline $\begin{array}{l}\text { OUTSIDE } \\
\text { THE FAÇADE }\end{array}$ & $13.9 \%$ fixations & $8.6 \%$ fixations & $7.9 \%$ fixations \\
\hline
\end{tabular}

Observers spent $86.9 \%$ of their time looking at the façade without the wedge. In the case of the image showing the transformed building, the old part of the façade attracted an average of $66.9 \%$ of the participants' time. The illumination in the nighttime picture contributed to an increase of this value to $75 \%$ (see table 2).

The strong axial composition and the importance of the central part of the arsenal's original design manifest themselves in the amount of time spent on observing them. The participants spent $43.9 \%$ of their time looking at this area (zone 6). As a result of the modern transformation the importance of the axis decreased - the slump in attention paid to this part of the image in the daytime image amounted to over 12 percentage points. However, the illumination in the nighttime image seems to ease the asymmetry effect (volunteers spent $38.7 \%$ of time looking at this zone). A similar effect is visible in the strong illumination of the niche located above the main entrance. In the original image it attracted $29 \%$ of attention, in the daytime image of the transformed building it was $20 \%$ of time and in the illuminated version it increased to $24.1 \%$.

It is interesting that an introduction of a new element, that is the wedge, changed the amount of attention paid to the avant-corps located on the sides of the façade. Those looking at the original symmetrical composition preferred to observe the right side of the building (zone 8). However, once the wedge is added (zone 5), the right side of the façade becomes less important and attractive. Obviously, this does not come as a surprise. What is astonishing, is the way that illumination affects the perception of the building. The lighting system makes the observers spend more time looking at the outermost side parts (zones 2 and 8) and reinstates the right side of the façade (zone 8) as a preferred spot, drawing particularly close attention.

What is more, although the illumination emphasizes the partial transparency of the wedge, it actually appears to reduce the time spent by observers on looking at this added element. The participants of the survey who looked at the daytime photo spent $24.5 \%$ of time on studying this particular part of the façade, while the same number equaled only $17.1 \%$ for the nighttime, illuminated image. 
Table 2. Analysis of attention paid to the visual zones. Comparison for the three studied stimuli.

\begin{tabular}{|c|c|c|c|c|c|c|}
\hline & \multicolumn{2}{|c|}{$\begin{array}{c}\text { BUILDING WITHOUT } \\
\text { THE WEDGE - } \\
\text { DAY } \\
\text { fig. } 2 \mathrm{C}\end{array}$} & \multicolumn{2}{|c|}{$\begin{array}{c}\text { BUILDING WITH THE } \\
\text { WEDGE - } \\
\text { DAY } \\
\text { fig. 2B }\end{array}$} & \multicolumn{2}{|c|}{$\begin{array}{c}\text { BUILDING WITH } \\
\text { THE WEDGE - } \\
\text { NIGHT } \\
\text { fig. 2D } \\
\end{array}$} \\
\hline $\begin{array}{l}\text { HISTORIC PART } \\
\begin{array}{r}\text { (ZONES 1, 2, 3, 4, 6, } \\
7,8) \\
\text { commentary }\end{array}\end{array}$ & \multicolumn{2}{|c|}{$\begin{array}{c}86.9 \% \\
-\end{array}$} & \multicolumn{2}{|c|}{$\begin{array}{l}\mathbf{6 6 . 9 \%} \\
\text { The added wedge } \\
\text { reduces the time spent } \\
\text { on the historic part by } \\
20 \text { percentage points }\end{array}$} & \multicolumn{2}{|l|}{$\begin{array}{r}\text { restores in } \\
\text { histo }\end{array}$} \\
\hline $\begin{array}{r}\text { CENTER } \\
\text { (ZONE 6) } \\
\text { commentary }\end{array}$ & \multicolumn{2}{|c|}{$\begin{array}{c}\mathbf{4 3 . 9 \%} \\
\text { Most centralized } \\
\text { composition }\end{array}$} & \multicolumn{2}{|c|}{$\begin{array}{c}\mathbf{3 1 . 6 \%} \\
\text { Decreases by } 12.3 \\
\text { percentage points in } \\
\text { comparison with } C\end{array}$} & \multicolumn{2}{|c|}{$\begin{array}{c}\mathbf{3 8 . 7 \%} \\
\text { Increases in } \\
\text { comparison to } B, \\
\text { gets closer to } C\end{array}$} \\
\hline $\begin{array}{r}\text { WEDGE } \\
\text { (ZONE 5) } \\
\text { commentary }\end{array}$ & \multicolumn{2}{|c|}{-} & \multicolumn{2}{|c|}{$24.5 \%$} & \multicolumn{2}{|c|}{$\begin{array}{c}\mathbf{1 7 . 1 \%} \\
\text { Decreases in } \\
\text { comparison to B }\end{array}$} \\
\hline $\begin{array}{l}\text { CENTRAL } \\
\text { AVANT-CORPS } \\
\text { (ZONE 6A) }\end{array}$ & \multicolumn{2}{|c|}{$40.1 \%$} & \multicolumn{2}{|c|}{$26.9 \%$} & \multicolumn{2}{|c|}{$35.6 \%$} \\
\hline $\begin{array}{l}\text { THE NICHE ON } \\
\text { CENTRAL } \\
\text { AVANT-CORPS } \\
\text { AXIS } \\
\\
\text { (ZONE 6B) } \\
\text { commentary }\end{array}$ & \multicolumn{2}{|c|}{ The niche most emphasized } & \multicolumn{2}{|c|}{$\begin{array}{l}\mathbf{2 0 . 0} \% \\
\text { The interest in the niche } \\
\text { decreases by } 9 \text { percentage } \\
\text { points in comparison to } C\end{array}$} & \multicolumn{2}{|c|}{$\begin{array}{c}\mathbf{2 4 . 1 \%} \\
\text { The niche more } \\
\text { emphasized than in } B, \\
\text { gets closer to } C\end{array}$} \\
\hline $\begin{array}{l}\text { OUTERMOST } \\
\text { AVANT-CORPS } \\
\\
\text { LEFT (ZONE 2) } \\
\text { RIGHT (ZONE 8) }\end{array}$ & $\begin{array}{l}\text { ZONE } 2 \\
\mathbf{6 . 6 \%}\end{array}$ & $\begin{array}{l}\text { ZONE } 8 \\
\mathbf{1 2 . 1 \%}\end{array}$ & $\begin{array}{l}\text { ZONE } 2 \\
\mathbf{8 . 9 \%}\end{array}$ & $\begin{array}{c}\text { ZONE } 8 \\
7.2 \%\end{array}$ & $\begin{array}{l}\text { ZONE } 2 \\
\mathbf{8 . 9 \%}\end{array}$ & $\begin{array}{c}\text { ZONE } 8 \\
\mathbf{1 0 . 2} \%\end{array}$ \\
\hline $\begin{array}{l}\text { OUTMOST } \\
\text { AVANT-CORPS } \\
\text { IN TOTAL } \\
(\text { ZONE } 2 \& 8)\end{array}$ & \multicolumn{2}{|c|}{$18.7 \%$} & \multicolumn{2}{|c|}{$16.1 \%$} & \multicolumn{2}{|c|}{$19.1 \%$} \\
\hline
\end{tabular}

\section{Conclusions}

The fact that the arsenal had been rebuilt after the Second World War without molding details made the building only moderately attractive from the visual point of view. An unremarkable seat constitutes a problem for a museum that cares about its image, reputation, and high attendance. The changes designed by Daniel Libeskind helped create a recognizable architectural symbol associated with this institution. Libeskind aimed at a bold transformation and evoking new, strong emotions in people looking at the building of the former arsenal. The numerical data obtained during the eye tracking survey suggests that by introducing the openwork wedge, the architect managed to achieve his goal.

What may prove surprising is the effect that the illumination of the building has on its perception. By placing the sources of the light in the way he did, Libeskind - most probably not on purpose - reduced the contrast between the new and the old parts in the structure of the building. That means that the illumination not only does not contribute to the achievement of Libeskind's intentions, but actually has a contrary effect. The perception of the illuminated façade is less dynamic. The lighting emphasizes the strong composition of the three avant-corps and the niche located above the main entrance. Contrary to what 
might have been expected, the illumination does not emphasize the added wedge, composed out of numerous overlapping layers, a spot that theoretically should be the most intriguing from the architectural point of view. Paradoxically, such lighting makes it easier to comprehend the original composition of the façade and thus reduces the effect obtained by adding the wedge - the effect that Libeskind was supposedly so eager to achieve.

The presented survey, in the authors' opinion, offers a real, more objective insight into how such a remarkable architectural object is perceived and into the influence of the changes introduced during the transformation. Hopefully, it might also serve as a spark igniting a much more detailed study and discussion, relating not only to this very building, but to the entire process of transforming historic monuments. Moreover, it seems to show that an eye tracker is an exceptionally valuable research tool, especially useful in architectural studies in which the way average observers perceive a given object is a key issue. Researchers who deal with conservation and architecture should strive to use new neuronal tools, including eye trackers in their activities. It can be used to verify theory [15] and to check things in practice [16-19]. We should not be too distrustful of them, which Łukasz Kędziora also suggests in his work [20]. The contemporary development of civilisation is increasingly blurring the differences between the humanities and exact mathematical sciences.

\section{Acknowledgements}

We would like to thank the following for the help in conducting the survey: Ewa Ramus, a representative of Neuro Device Group; the Student Research Club "ArcHist" and students Piotr Chmielewski, Mateusz Ratajczak, Jakub Biernacki, Filip Kuklewski, Daryia Sidarevich, and Natalia Torbiaczyk. We would also like to thank all the volunteers who participated in our research.

\section{Reference}

1. D. Mączyński, Renowacje i Zabytki, 2, 94-109 (2004)

2. E. Łapa, Jaśnieje oświecony Kraków, in: Krakowski Rynek Nieruchomości 6/2010 (2010), ttps://dwutygodnik.krn.pl/artykuly/artykul/jasnie_oswiecony_krakow_892.html (acessed 27.06.2017)

3. M. Witwicki, (Aktualne problemy iluminacji obiektów zabytkowych, in: Instalator, 2006)

4. P. Stępień, Renowacje, 6, 48-54 (1999)

5. M. Sulma, Krakowska Teka Konserwatorska, 1, (2000)

6. T. Duchowski., (Eyetracking methodology. Theory and practice, 2007)

7. R. Anderson., R. Dewhurst, K. Holmqvist, H. Jarodzka, M. Nystöm, J. van de Weije, (Eye tracking. A comprehensive guide to metods and measures, 2001)

8. https://libeskind.com/work/military-history-museum/, \{acessed 28.06.2018\}

9. https://www.mhmbw.de/exhibition, \{acessed 06.06.2018\}

10. D. Libeskind, (Przełom: przygody o życiu i architekturze, 2008)

11. http://www.bryla.pl/bryla/1,85298,10489120,Muzeum_Wojskowosci_w_Dreznie.html \{acessed 06.06.2017\}

12. M Rotem, S Shosh, Constructing Memory : Architectural Narratives of Holocaust Museums, 141-155, (2013)

13. M. Rusnak, (Nowe muzeum czy ekspozycja w zabytku: możliwość zachowania przekazu historycznego. w: Przyszłość architektury, pod red. E. Przesmycka E. TrockaLeszczyńska, Wydział Architektury Politechniki Wrocławskiej, 197-210, 2014)

14. S. A. Holllander, Cognitive Architecture (2015) 
15. Rusnak M., Fikus W., Szewczyk J., Architectus 1(53), 77-88 (2018)

16. R. Wawer, D. Olesiuk, (Przestrzeń byłego obozu koncentracyjnego na Majdanku jako eksponat muzealny i obiekt analiz eye trackingowych, in: Muzeum Formy i środki prezentacji, 87-101, 2013)

17. Wawer R., Pakuła M., Zeszyty naukowe Uniwersytetu Szczecińskiego 703, 698-707 (2012)

18. http://pwr.edu.pl/uczelnia/aktualnosci/nietypowe-badania-zwiazane-z-architekturamozesz-pomoc-naukowcom-z-w1-10401.html, \{accessed 28.06.2018\}

19. http://pwr.edu.pl/uczelnia/aktualnosci/jak-patrzymy-na-architekture-badania-zuzyciem-eye-trackera-i-gogli-vr-10809.html, \{acessed 28.06.2018\}

20. Kędziora Ł., Zabytkoznawstwo i Konserwatorstwo”, 45, 223-252 (2014) 